\title{
KAJIAN SIFAT ORGANOLEPTIK DAN DAYA TERIMA ES KRIM JALOR (JAMBU BIJI DAN SARI DAUN KELOR)
}

\author{
Nadya Natasya* \\ Jurusan Gizi, Poltekkes Kemenkes Mataram, Indonesia \\ Jl. Praburangkasari Dasan Cermen, Sandubaya Kota Mataram \\ Email : nadyanatasyaalaydrus@gmail.com
}

\begin{tabular}{l} 
Article Info \\
Article history: \\
Received January $14^{\text {th }}, 2019$ \\
Revised February $15^{\text {th }}, 2019$ \\
Accepted March $20^{\text {th }}, 2019$ \\
\hline
\end{tabular}

\section{Keyword:}

Guava, Ice Cream, Moringa

\begin{abstract}
Background: Young women generally have characteristics of unhealthy meal habits and many of them lack of nutrients needed, so there is a need to have an alternative nutritionally rich and attractive food product through the manufacture of JALOR Ice Cream which is produced from Milk, Guava and Moringa Leaf Extract, to increase iron in order to prevent iron deficiency.
\end{abstract}

Methods: This study was conducted using an experimental research design. The experiment was carried out using a Completely Randomized Design (CRD) using 5 treatments with the addition of Moringa Leaf Extract: $t 1$ (10\%), t2 (20\%), t3 (30\%), t4 (40\%) and t5 (50\%). The experiment were carried out on hedonic tests on 20 panelists with 5 scales, namely: $5=$ Very like, $4=$ Like, $3=$ Neutral, 2 = Dislike, and 1 = Very dislike. Acceptance test was conducted on young women.

Result: The results of the organoleptic test showed that JALOR Ice Cream was chosen on treatment 2 with the addition of $20 \%$ Moringa Leaf Extract. The results of the adolescent girls' acceptance of selected JALOR Ice Cream products showed that all (100\%) panelists were at the level of good category.

Conclusion: JALOR Ice Cream is with the addition of 20\% Moringa Leaf Extract is the most preffered. The acceptance of Ice Cream can be well received by panelists.

\section{PENDAHULUAN}

Masalah gizi merupakan masalah kesehatan masyarakat utama di Indonesia dimana salah satu masalah gizi tersebut adalah Anemia. Angka anemia di Indonesia sebanyak 84,6\% pada remaja putri dan ibu hamil (Riskesdas, 2018).

Remaja putri merupakan salah satu kelompok yang lebih rawan menderita anemia daripada remaja laki-laki dimana kebutuhan zat besi pada remaja putri lebih tinggi, karena kehilangan zat besi selama menstruasi. (Badriah, 2011).

Remaja putri merupakan generasi masa depan bangsa yang nantinya akan menentukan generasi berikutnya karena remaja putri memiliki konstribusi besar pada kesehatan, keselamatan kehamilan dan kelahiran apabila remaja putri menjadi ibu. Status gizi dan kesehatan ibu pada masa pra-hamil merupakan periode yang sangat kritis bagi pertumbuhan dan perkembangan anak dimana pada masa 1000 Hari Pertama Kehidupan anak merupakan periode sensitif yang apabila pada masa ini anak mengalami masalah gizi maka 
akibat yang ditimbulkan sangat beresiko sehinggpa perlu pencegahan gizi kurang pada ibu hamil mulai dari usia remaja (Prabandari et al., 2016).

Dalam konsumsi makanan sehari-hari remaja umumnya memiliki karakteristik kebiasaan makan tidak sehat sehingga remaja tidak mampu memenuhi keanekaragaman zat makanan yang dibutuhkan oleh tubuhnya khususnya zat besi untuk proses pembentukan hemoglobin (Suryani, et al., 2015).

Menurut Hasdianah, et al. (2014), agar zat besi yang diabsorbsi lebih banyak tersedia oleh tubuh, maka diperlukan bahan makanan yang berkualitas tinggi seperti pada sayuran hijau, selain itu bahan makanan yang tinggi vitamin $\mathrm{C}$ membantu penyerapan zat besi seperti yang terkandung dalam buah-buahan. Mencegah persoalan kurang zat gizi besi ini dapat dilakukan dengan mengkonsumsi makanan yang mengandung zat besi. Salah satunya adalah dengan pengembangan produk Es Krim dengan penambahan sayur dan buah yang memiliki kandungan zat besi dan vitamin $\mathrm{C}$ yang tinggi.

Produk Es Krim dipilih karena merupakan produk yang telah berkembang dan diminati masyarakat luas, mulai dari anak-anak hingga kalangan lanjut usia. Es krim merupakan salah satu makanan yang digemari masyarakat karena keunikan dan pilihan rasa yang banyak membuat es krim semakin menarik. Selain itu Es krim juga merupakan produk yang dinilai dapat memenuhi persyaratan sebagai makanan selingan bagi remaja untuk memenuhi angka kecukupan gizi remaja melalui pengembangan produk es krim (Hartatie, 2011).

Kelor merupakan salah satu jenis sayuran yang memiliki kandungan zat besi yang tinggi serta memiliki nilai ekonomis yang cukup baik. Daun Kelor (Moringa oleifera) merupakan tumbuhan sayuran yang banyak terdapat di Asia Tenggara. Kelor merupakan (Moringa oleifera) tanaman yang mempunyai zat gizi tinggi, sebagai antioksidan, antibakteri, mengandung beta karoten, thiamin (B1), riboflavin (B2), niacin (B3), kalsium, fosfor, magnesium, seng, zat besi. Zat besi tinggi yang terkandung dalam kelor baik untuk mencegah Anemia (Aminah et al., 2015). Selain itu agar zat besi yang diabsorbsi lebih banyak tersedia oleh tubuh, maka diperlukan bahan makanan yang mengandung vitamin $\mathrm{C}$ yang tinggi untuk membantu penyerapan zat besi seperti yang terkandungan dalam buah Jambu Biji.

Berdasarkan uraian tersebut maka perlu kajian dalam pembuatan es krim yang ditambahkan atau dimodifikasi dengan penambahan sari daun kelor. Dengan demikian dilakukan uji organoleptik dan daya terima Es Krim JALOR (Jambu Biji dan Sari Daun Kelor) dengan penambahan sari daun kelor.

\section{Tujuan Penelitian}

Untuk mengkaji sifat organoleptik Es Krim JALOR (Jambu Biji dan Sari Daun Kelor) dengan 5 perlakuan $(10 \%, 20 \%, 30 \%, 40 \%$, dan 50\%) serta untuk mengkaji daya terima Es Krim JALOR (Jambu Biji dan Sari Daun Kelor).

\section{METODE PENELITIAN}

\section{Rancangan dan Desain Penelitian}

Jenis penelitian yang digunakan adalah jenis penelitian eksperimental. Percobaan dilakukan dengan menggunakan Rancangan Acak Lengkap (RAL) dengan 5 perlakuan dan pengulangan sebanyak 3 kali. Perlakuan dalam penelitian ini adalah sebagai berikut:

$\mathrm{t} 1=$ Penambahan Sari Daun Kelor 10\%

t2 = Penambahan Sari Daun Kelor 20\%

t3 $=$ Penambahan Sari Daun Kelor 30\%

t4 = Penambahan Sari Daun Kelor 40\%

t5 $=$ Penambahan Sari Daun Kelor 50\%

\section{Teknik Pengumpulan}

Data pengamatan dilakukan secara organoleptik yaitu dilakukan pengamatan terhadap warna, aroma, rasa dan tekstur secara keseluruhan. Pengujian organoleptik terhadap Es Krim JALOR dilakukan uji hedonik dengan 5 skala yaitu skala $5=$ sangat suka, $4=$ suka, $3=$ netral, $2=$ tidak suka, dan $1=$ sangat tidak suka. Dengan cara disediakan, kemudian panelis diminta untuk memberikan penilaiannya terhadap masingmasing sampel berdasarkan kriteria yang dapat dilihat pada form uji hedonik.

\section{Analisis Data}

Data yang diperoleh dari hasil pengamatan disajikan dalam bentuk tabel. Untuk mengetahui sifat organoleptik (warna, aroma, rasa, dan tekstur) dari setiap penambahan sari daun kelor terhadap sifat organoleptik es krim sedangkan untuk melihat daya terima konsumen dari setiap presentase penambahan sari daun kelor terhadap daya terima es krim jambu dianalisis sederhana dengan melihat makanan tarsisa. 
Untuk melihat daya terima Es Krim JALOR dapat dihitung dengan cara:

$$
\frac{\text { Berat Es Krim yang dihabiskan }}{\text { Berat Es Krim yang disajikan }} \times 100 \%
$$

Presentase uji daya terima berdasarkan kuantitas makanan yang dihabiskan menurut Kemenkes RI (2013) dapat dikelompokkan menjadi:

- $\quad$ Daya terima baik jika makanan dihabiskan $\geq 80 \%$.

- $\quad$ Daya terima kurang jika makanan yang dihabiskan $<80 \%$.

\section{HASIL PENELITIAN}

Warna

Secara visual, faktor warna tampilan lebih dahulu dan kadang sangat menentukan nilai mutu sebuah produk makanan. Suatu bahan yang dinilai bergizi, enak, dan teksturnya sangat menarik akan dimakan apabila memiliki warna yang menarik dipandang. Selain itu warna juga dapat digunakan sebagia indikator kesegaran atau kematangan. Baik atau tidaknya cara pencampuran atau cara pengolahan dapat ditandai dengan adanya warna yang seragam dan merata (Winarno, 2004).

Berdasarkan hasil analisis sederhana dengan menghitung rata-rata tingkat kesukaan panelis terhadap penambahan sari daun kelor pada warna Es Krim JALOR (Jambu Biji dan Sari Daun Kelor) dapat dilihat dalam Tabel 1.

Tabel 1. Hasil rata-rata skor kesukaan panelis terhadap warna Es Krim JALOR (Jambu Biji dan Sari Daun Kelor)

\begin{tabular}{ccc}
\hline No. & Perlakuan & Rata-rata Skor Nilai Variable Warna \\
\hline 1 & t1 (Penambahan Sari Daun Kelor 10\%) & 4,00 \\
2 & t2 (Penambahan Sari Daun Kelor 20\%) & 4,25 \\
3 & t3 (Penambahan Sari Daun Kelor 30\%) & 4,15 \\
4 & t4 (Penambahan Sari Daun Kelor 40\%) & 3,90 \\
5 & t5 (Penambahan Sari Daun Kelor 50\%) & 3,65 \\
\hline
\end{tabular}

Berdasarkan tabel didapatkan bahwa rata-rata tingkat kesukaan panelis terhadap warna Es Krim JALOR yakni 4,25 dengan aras perlakuan t2 (penambahan Kelor 20\%) dan skor terendah 3,65 pada perlakuan t5 (penambahan Kelor 50\%).

Perbedaan warna pada kelima perlakuan es krim terutama dipengaruhi oleh penambahan kelor dimana warna es krim pada perlakuan $\mathrm{t} 1$ adalah hijau muda, pada t2 berwarna hijau agak tua, pada $\mathrm{t} 3$ berwarna hijau tua, pada 4 berwarna hijau gelap, dan pada t5 berwarna hijau pekat. Perbedaan inilah yang membuat panelis lebih menyukai es krim dengan penambahan kelor pada perlakuan $\mathrm{t} 2$ sehingga perlakuan $\mathrm{t} 2$ lebih menarik dibandingkan perlakuan lainnya.

\section{Aroma}

Aroma menentukan kelezatan bahan makanan tersebut. Dalam hal aroma lebih banyak bersangkutan dengan panca indera pembau. Aroma baru dapat dikenali bila terbentuk uap, dan molekulmolekul komponen pembau tersebut harus sempat menyentuh sillia sel olfaktori dan diteruskan ke otak dalam bentuk implus listrik oleh ujung-ujung saraf olfaktori (Winarno, 2004).

Aroma yang disebarkan oleh makanan merupakan daya tarik yang sangat kuat dan mampu merangsang indera penciuman sehingga membangkitkan selera (Yulita, 2017).

Berdasarkan hasil analisis sederhana dengan menghitung rata-rata tingkat kesukaan panelis terhadap penambahan daun kelor pada aroma Es Krim JALOR (Jambu Biji dan Sari Daun Kelor) dapat dilihat dalam Tabel 2. 
Tabel 2. Hasil rata-rata skor kesukaan panelis terhadap aroma Es Krim JALOR (Jambu Biji dan Sari Daun Kelor)

\begin{tabular}{ccc}
\hline No. & Perlakuan & Rata-rata Skor Nilai Variable Aroma \\
\hline 1 & t1 (Penambahan Sari Daun Kelor 10\%) & 3,95 \\
2 & t2 (Penambahan Sari Daun Kelor 20\%) & 3,85 \\
3 & t3 (Penambahan Sari Daun Kelor 30\%) & 3,80 \\
4 & t4 (Penambahan Sari Daun Kelor 40\%) & 3,75 \\
5 & t5 (Penambahan Sari Daun Kelor 50\%) & 3,65 \\
\hline
\end{tabular}

Berdasarkan tabel didapatkan bahwa rata-rata tingkat kesukaan panelis terhadap aroma Es Krim JALOR yakni 3,95 dengan aras perlakuan t1 (penambahan Kelor 10\%) dan skor terendah 3,65 pada perlakuan t5 (penambahan Kelor 50\%).

Tidak adanya perbedaan yang signifikan dari aroma kelima perlakuan es krim. Hal ini dikarenakan salah satu bahan dasar dalam pembuatan es krim yaitu susu dan jambu biji sehingga aroma khas kelor tertutupi dan aroma yang dihasilkan seimbang.

\section{Rasa}

Rasa berbeda dengan aroma dan lebih banyak menentukan kelezatan bahan kanana tersebut. Dalam hal rasa lebih banyak melibatkan panca indera lidah. Penginderaan pengecapan dapat dibagi menjadi empat cecapan utama yaitu asin, asam, manis, dan pahit (Winarno, 2004).

Berdasarkan hasil analisis sederhana dengan menghitung rata-rata tingkat kesukaan panelis terhadap penambahan sari daun kelor pada rasa Es Krim JALOR (Jambu Biji dan Sari Daun Kelor) dapat dilihat dalam Tabel 3.

Tabel 3. Hasil rata-rata skor kesukaan panelis terhadap rasa Es Krim JALOR (Jambu Biji dan Daun

\begin{tabular}{|c|c|c|}
\hline \multicolumn{3}{|c|}{ Kelor) } \\
\hline No. & Perlakuan & Rata-rata Skor Nilai Variable Rasa \\
\hline & t1 (Penambahan Sari Daun Kelor 10\%) & 4,40 \\
\hline 2 & t2 (Penambahan Sari Daun Kelor 20\%) & 4,50 \\
\hline 3 & t3 (Penambahan Sari Daun Kelor 30\%) & 4,20 \\
\hline 4 & t4 (Penambahan Sari Daun Kelor 40\%) & 4,05 \\
\hline 5 & t5 (Penambahan Sari Daun Kelor 50\%) & 3,85 \\
\hline
\end{tabular}

Berdasarkan tabel didapatkan bahwa rata-rata tingkat kesukaan panelis terhadap rasa Es Krim JALOR yakni 4,50 dengan aras perlakuan t2 (penambahan Kelor 20\%) dan skor terendah 3,85 pada perlakuan t5 (penambahan Kelor 50\%).

Perbedaan rasa dari pada kelima perlakuan terutama dipengaruhi oleh penggunaan bahan dasar yaitu susu, jambu biji, dan kelor. Penggunaan kelor pada es krim memberikan rasa yang berbeda dibandingkan es krim pada umumnya. Perbedaan inilah yang membuat perlakuan t2 lebih menarik karena rasa pahit dari kelor tertutupi dengan rasa jambu biji susu.

\section{Tekstur}

Tekstur dan konsistensi suatu bahan akan mempengaruhi cita rasa yang ditimbulkan oleh bahan tersebut. Perubahan tekstur bahan dapat mengubah rasa dan bau yang timbul karena dapat mempengaruhi kecepatan timbulnya rangsangan terhadap sel reseptor olfiktori dan kelenjar liur (Winarno, 2004).

Berdasarkan hasil analisis sederhana dengan menghitung rata-rata tingkat kesukaan panelis terhadap penambahan sari daun kelor pada tekstur Es Krim JALOR (Jambu Biji dan Sari Daun Kelor) dapat dilihat dalam Tabel 4. 
Tabel 4. Hasil rata-rata skor kesukaan panelis terhadap tekstur Es Krim JALOR (Jambu Biji dan Sari Daun Kelor)

\begin{tabular}{ccc}
\hline No. & Perlakuan & Rata-rata Skor Nilai Variable Tekstur \\
\hline 1 & t1 (Penambahan Sari Daun Kelor 10\%) & 3,90 \\
2 & t2 (Penambahan Sari Daun Kelor 20\%) & 4,05 \\
3 & t3 (Penambahan Sari Daun Kelor 30\%) & 3,85 \\
4 & t4 (Penambahan Sari Daun Kelor 40\%) & 3,95 \\
5 & t5 (Penambahan Sari Daun Kelor 50\%) & 3,75 \\
\hline
\end{tabular}

Berdasarkan tabel didapatkan bahwa rata-rata tingkat kesukaan panelis terhadap tekstur Es Krim JALOR yakni 4,05 dengan aras perlakuan t2 (penambahan Kelor 20\%) dan skor terendah 3,75 pada perlakuan t5 (penambahan Kelor 50\%).

Tidak adanya perbedaan secara signifikan dari tekstur pada kelima perlakuan es krim. Tekstur dari kelima perlakuan es krim lembut dan tidak mengkristal. Hal ini dipengaruhi oleh bahan whippy cream serta cara pengolahan dengan cara memblender semua bahan hingga menjadi halus.

\section{Perlakuan Terbaik}

Untuk penentuan hasil Es Krim yang disukai dapat dilihat pada Tabel 5.

Tabel 5. Perlakuan Terbaik

\begin{tabular}{cccccc}
\hline \multirow{2}{*}{$\begin{array}{c}\text { Perlakuan } \\
\text { Penambahan Kelor }\end{array}$} & \multicolumn{4}{c}{ Parameter Uji } & \multirow{2}{*}{ Jumlah } \\
\cline { 2 - 4 } & Warna & Aroma & Rasa & Tekstur & \\
\hline t1 & 4,00 & 3,95 & 4,40 & 3,90 & 16,25 \\
t2 & 4,25 & 3,85 & 4,50 & 4,05 & 16,65 \\
t3 & 4,15 & 3,80 & 4,20 & 3,85 & 16,00 \\
t4 & 3,90 & 3,75 & 4,05 & 3,95 & 15,65 \\
t5 & 3,65 & 3,65 & 3,85 & 3,75 & 14,90 \\
\hline
\end{tabular}

Berdasarkan tabel diatas dapat dilihat perlakuan $\mathrm{t} 2$ memiliki daya terima yang lebih tinggi dalam hal warna, rasa, dan tekstur. Maka dilakukan Uji Daya Terima pada aras perlakuan $\mathrm{t} 2$.

Hal ini karena pada aras perlakuan $\mathrm{t} 2$ warna yang dimiliki yaitu hijau terang dan tidak terlalu pekat, dengan rasa khas dari kelor yang tertutupi oleh rasa dari jambu biji dan susu, serta tekstur yang lembut sehingga memiliki daya terima yang lebih tinggi dengan total skor 16,65 .

\section{Daya Terima}

Daya terima makanan adalah kesanggupan seseorang dalam menghabiskan makanan yang disajikan menurut tingkat kesukaan atau ketidaksukaan individu terhadap suatu jenis makanan. Tingkat kesukaan ini sangat beragam pada setiap individu sehingga akan berpengaruh terhadap konsumsi pangan (Susiwi, 2009).

Uji daya terima dilakukan pada tanggal 18 Maret 2019. Uji daya terima dilakukan oleh 20 orang panelis remaja putri berumur 13 - 15 tahun terhadap formula terpilih t2 dengan penambahan Kelor $20 \mathrm{~g}$ untuk kebutuhan remaja usia 13 - 15 tahun menurut AKG 2013 yaitu Energi dari 56 g Es Krim yaitu 212 kkal sedangkan untuk Protein yaitu 13,8 g, dan Zat Besi 26 mg. Konstribusi berat Es Krim bisa memenuhi 212 kkal dari 10\% kebutuhan remaja dan protein bisa memenuhi 20\% dari kebutuhan protein remaja 13 - 15 usia tahun. Dengan demikian Es Krim merupakan Es Krim yang mengandung Protein dan Zat Besi tinggi.

Berdasarkan hasil uji daya terima pada 20 orang panelis didapatkan bahwa sebanyak 20 orang panelis termasuk dalam kategori baik dengan presentase 100\%. Hal ini dikarenakan es krim tersebut memiliki warna hijau terang; perpaduan antara aroma khas kelor, jambu biji, dan susu; perpaduan antara rasa khas kelor, jambu biji, dan susu; serta tekstur yang lembut menjadikan es krim ini menarik karena komposisinya yang berbeda dibandingkan es krim pada umumnya sehingga es krim ini dapat direkomendasikan kepada remaja maupun masyarakat berdasarkan daya terimanya. 


\section{KESIMPULAN}

Es Krim JALOR (Jambu Biji dan Sari Daun Kelor) yang memiliki sifat organoleptik yang paling disukai yaitu dengan penambahan Sari Daun Kelor sebanyak 20\% dari berat bahan dasar dan dalam uji daya terima dapat diterima dengan baik oleh panelis (100\%).

\section{SARAN}

Untuk membuat Es Krim JALOR sebaiknya menggunakan penambahan sari daun kelor sebanyak 20\% untuk menghasilkan warna, aroma, rasa dan tekstur baik. Diharapkan Es Krim JALOR (Jambu Biji dan Sari Daun Kelor) dapat dijadikan sebagai makanan selingan padat gizi bagi remaja dan juga untuk mencegah defisiensi zat besi karena Es Krim JALOR mengandung zat besi yang tinggi serta Vitamin C yang tinggi untuk mempercepat penyerapan zat besi.

\section{DAFTAR PUSTAKA}

Aminah, S., T. Ramdhan dan M. Yanis. 2015. Kandungan Nutrisi dan Sifat Tanaman Kelor. Jakarta: Balai Pengkajian Teknologi Pertanian Jakarta

Badan Penelitian dan Pengembangan Kesehatan. Kementrian Kesehatan Republik Indonesia. 2018. Jakarta: Riset Kesehatan Dasar.

Badan Standarisasi Nasional. 1995. Es Krim. SNI No. 01-3713-1995. Jakarta.

Badriah, D. L. 2011. Gizi dalam Kesehatan Reproduksi. Bandung: PT. Refika Aditama.

Faubun, S. dan H. Sinay. 2016. Kadar Lemak Es Krim Tepung Daun Kelor berdasarkan Variasi Volume Sari Kacang Tanah. Maluku: Universitas Pattimura.

Hartatie, E. S. 2011. Kajian Formulasi (Bahan Baku, Bahan Pemantap) dan Metode Pembuatan Terhadap Kualitas Es Krim.

Indriany, D. S. 2017. Penggunaan Sari Jambu Biji terhadap Kualitas Es Krim. Padang: Universitas Negeri Padang.

Mulyani, N. S. 2016. Pengaruh Penambahan Tepung Maizena terhadap Daya Terima Es Krim Jambu Biji. Aceh: Poltekkes Kemenkes Aceh.

Rahayu. 1998. Penuntun Praktikum Penilaian Organoleptik. Bogor: Fakultas Teknologi Pertanian.

Pawarti, G. 2011. Pembuatan Es Krim dengan Penambahan Daun Pepaya sebagai Zat Anti Kanker. Surakarta: Universitas Sebelas Maret.

Prabandari, Y., D. Hanim, R. Cilmiaty dan D. Indarto. 2016. Hubungan Kurang Energi Kronik dan Anemia pada Ibu Hamil dengan Status Gizi Bayi Usia 6-12 bulan di Kabupaten Boyolali. Surakarta: Universitas Sebelas Maret.

Saputro, D. W. 2014. Pemanfaatan Kacang Tolo sebagai Bahan Tambahan Es Krim dengan Pewarna Alami Daun Bayam. Surakarta: Universitas Muhammadiyah Surakarta.

Setiyaningsih, D., A. Apriyantono dan M. P. Sari. 2010. Analisis Sensori untuk Industri Pangan dan Agro. Bogor: Institut Pertanian Bogor Press.

Suryani, D., R. Hafiani dan R. Junita. 2015. Analisis Pola Makan dan Anemia Gizi Besi pada Remaja Putri Kota Bengkulu. Bengkulu.

Susiwi, S. 2009. Penilaian Organoleptik. Bandung: Universitas Pendidikan Indonesia. 
ISSN: 2656-2456 (Online)

ISSN: 2356-4075 (Print)

Winarno. 2004. Kimia Pangan dan Gizi. Jakarta: Gramedia Pustaka Utama.

Yulita, I. 2017. Uji Daya Terima dan Kandungan Zat Gizi Es Krimdengan Modifikasi Bunga Rosella. Medan: Universitas Sumatera Utara. 